\title{
Pricing of Covered Warrants: An Analysis on Borsa İstanbul'
}

\author{
Melek AKSU (https://orcid.org/0000-0003-2906-1117), Department of Business Administration, Ballkesir \\ University, Turkey; e-mail: maksu@balikesir.edu.tr
}

Şakir SAKARYA (https://orcid.org/0000-0003-2510-7384), Department of Business Administration, Ballkesir University, Turkey; e-mail: sakarya@balikesir.edu.tr

\section{Hisse Senedine Dayalı Yatırım Kuruluşu Varantlarının Fiyatlaması: Borsa İstanbul'da Bir Uygulama²}

\begin{abstract}
This paper examines the pricing of 23 call and 23 put covered warrants based on Eregli Demir Celik Fabrikaları T.A.S. stocks, issued and expired in 2015. Black-Scholes, and Gram-Charlier pricing models are used to price covered warrants. Empirical results show that pricing performance of BlackScholes model is better for call warrants while pricing performance of Gram-Charlier model is better for put warrants. It is also indicated that observed market prices are irrationally higher than model prices and both of models are not so succesfull for pricing warrants in Turkey.

Keywords : Covered Warrants, Black-Scholes, Gram-Charlier, Pricing.

JEL Classification Codes : G10, G12.

$\ddot{\mathbf{O z}}$

Bu çalışmada 2015 yılında ihraç edilmiş ve aynı yıl vadesi dolmuş Ereğli Demir Çelik A.Ş. hisse senetlerine dayalı 23 adet alım ve 23 adet satım yatırım kuruluşu varantının piyasada doğru fiyatlanıp fiyatlanmadığı araştııılmıştır. Varantları fiyatlamak için literatürde yer alan Black-Scholes ve Gram-Charlier opsiyon fiyatlama modellerinden yararlanılmıştır. Çalışmanın sonucunda Ereğli Demir Çelik A.Ş. hisselerine dayalı varantların piyasa fiyatlarının, modeller yardımıyla hesaplanan teorik fiyatlara göre yüksek olduğu tespit edilmiştir. Black-Scholes fiyatlama modelinin alım varantlarını Gram-Charlier'e göre daha doğru fiyatladığı ve satım varantlarının fiyatlamasında da Gram-Charlier modelinin tercih edilebileceği ve her iki modelin de Türkiye'de varantları fiyatlama konusunda çok başarılı olmadığı tespit edilmiştir. $\mathrm{Bu}$ sonuçlar doğrultusunda bu modellerin Türkiye'deki varantları fiyatlamak için uygun olmadığı yorumu yapılabilmektedir.
\end{abstract}

Anahtar Sözcükler $\quad$ : Yatırım Kuruluşu Varantı, Black-Scholes, Gram-Charlier, Fiyatlama.

1 This article is the revised version of the master thesis titled as "Pricing Covered Warrants: An Analysis on Borsa Istanbul" which was presented by Melek Aksu in Ballkesir University, on June 28, 2016 under supervision of Prof. Şakir Sakarya.

2 Bu çalışma, Prof.Dr. Şakir Sakarya danışmanlığında, Melek Aksu tarafindan hazırlanan, 28.06.2016 tarihinde Balıkesir Üniversitesi Sosyal Bilimler Enstitüsü Işsletme Anabilim Dalı'nda savunulan "Hisse Senedine Dayalı Yatırım Kuruluşu Varantlarının Fiyatlamast: BIST'te Bir Uygulama” başlıkl yüksek lisans tezinden türetilmiştir. 


\section{Introduction}

It is no doubt that most or all kinds of investment involve some forms of risk. In the financial markets, financial derivatives are used by investors to control investment risks. One of the common question of the investors is what the price of the financial derivatives will be (Jiratumpradub \& Chavanasporn, 2016). Determining the theoretical price for financial derivatives is regarded as one of the most important issues in financial research. Accurately calculating financial derivatives' current price or forecasting its future price helps investors to make wise decisions in a more effective fashion (Liang \& Zhang \& Xiao \& Chen, 2009: 3055). The forecasting activity should realistically identify the financial derivatives' price in the future without knowing underlying asset price in advance (Liang \& Zhang \& Li, 2009: 586).

In all over the world, investors are searching for new investment opportunities to get higher returns in emerging markets. However, emerging markets are the most volatile markets with higher risk premiums than developed markets. For this reason, derivatives markets and efficient pricing models are crucial for hedging purposes in emerging markets (Alp, 2016: 70). Policymakers or regulators should care that the pricing of financial derivatives has diverged from their theoretical values; hence the market is very large and the potential systemic risks of a mispricing of such a large market cannot be dismissed. Derivatives prices also have become integral to many regulatory frameworks themselves. Regulators accept derivatives contracts as risk-limiting hedges for banks' asset portfolios. In many jurisdictions, the calculations of insurance company and pension fund liabilities reference swap rates: mispriced derivatives have consequences for real-world pensions and insurance contracts (Mutkin, 2015).

Covered warrants which are securitized options have been traded in Turkey since 2010. The warrants market has a very short history in Turkey. Covered warrants may improve financial depth and width in Turkey. Despite covered warrants' growing market size and significance, there are a few researches on covered warrants market in Turkey. Pricing of covered warrants has not been studied as much as pricing equity warrants on literature. This study contributes to the literature by pricing covered warrants using a method of Gram-Charlier that is used to price options and not used to price warrants before. This study investigates the pricing efficiency of Black-Scholes and Gram-Charlier models on covered warrants in Turkey. The purpose of this paper is to attempt to price covered warrants issued and expired between January, 2015 and December, 2015 and based on Eregli Demir ve Celik Fabrikaları T.A.S. stocks and to determine whether these models are appropriate to price covered warrants in Turkey.

The rest of the study is organized as follows. Following section gives information about covered warrants market of Turkey. Section 3 presents warrant pricing models. Section 4 reviews the relevant literature. Section 5 describes the data and methodology. Section 6 interprets the empirical results, and last section concludes. 


\section{Covered Warrants Market in Turkey}

Covered warrants are securitized options that give the holder the right, but not the obligation, to either buy or sell an underlying asset like equity (equity of other companies), index, currency and commodities (gold and oil) at a predetermined price (exercise price) on or before a certain date in the future (expiry date) (London Stock Exchange, 2016). Covered warrants and equity warrants have similar definitions, but there are several differences between them. The most significant difference between covered and equity warrants is that covered warrants are issued by banks or financial institutions and based on other companies' stocks, commodities or currencies, while equity warrants are issued by companies and based on own stocks (Ekstrand, 2011: 196; Temple, 2007: 143).

The investors have different cultural bias, psychological modes, life expectations and scarce budget in Turkey and need to a diversified portfolio for investing and hedging. The different types of covered warrants have been emerged to satisfy investors' different needs and expectations in Turkey in 13 August 2010.

The World Federation of Exchanges categorizes exchange of Turkey (BIST) between Europe-Africa-Middle East exchanges. BIST has been issuing structured products since 2010 according to statistics of The World Federation of Exchanges. It means that Turkey started to issue structured products with covered warrants in 2010. After 2010, the number of issued structured products, number of trading and trading volume have been increasing as shown in Figure 1 and 2. This can be a signal to development of covered warrants.

Figure: 1

\section{The Number of Structured Products in Turkey}

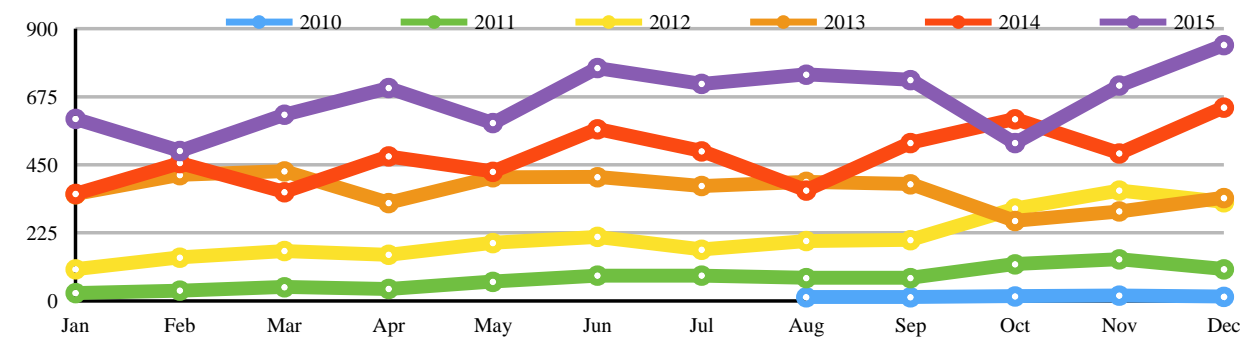

*Prepared by the author according to WFE statistics. 
Figure: 2

The Number and Volume of Transactions of Structured Products in Turkey

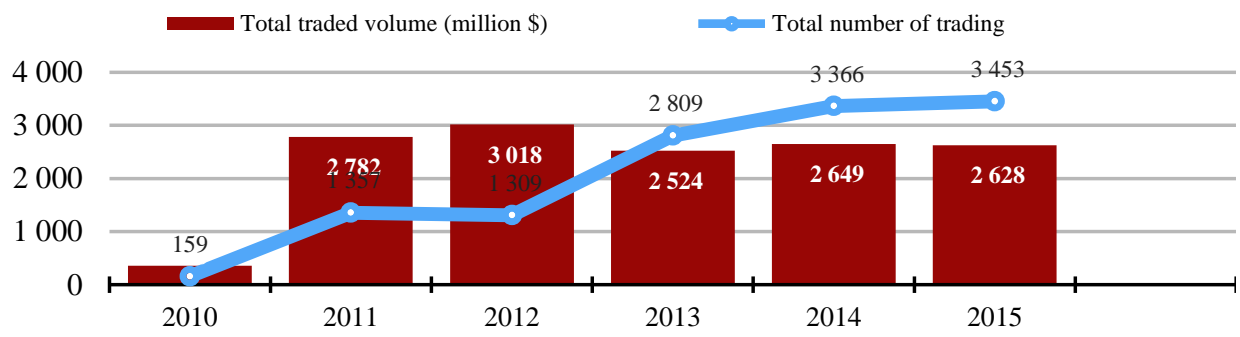

*Prepared by the author according to WFE statistics.

According to the statistics of Turkish Capital Markets Association, the number of investors who invest in covered warrants has been increasing as is seen from Figure 3. The number of investors is around 1.500 in 2011, and then increases to 2.500 in 2014.

Figure: 3

The Number of Covered Warrants Investors in Turkey Between 2011-2015

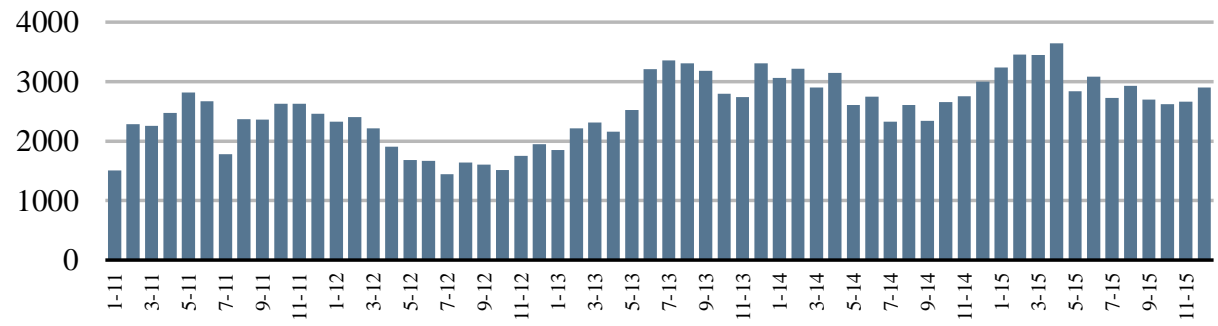

*Prepared by the author according to Turkish Capital Markets Association statistics.

Three institutions issue covered warrants in Turkey; IS Investment, Deutsche Bank and Garanti Bank. The law allows to issue American or European types of covered warrants based on stocks included in BIST 30 index and a basket of these stocks, convertible exchanges, commodities, stock indexes prepared by BIST, and indexes that are accepted internationally. However, there are only European covered warrants in the market of Turkey. The covered warrants are traded on the Market of Collective Investment and Structured Products under BIST.

Deutsche Bank has been issuing covered warrants based on S\&P 500, Dow Jones Industrial Average, NASDAQ 100, EURO STOXX 50, DAX, FTSE 100 and Nikkei 225 indexes, stocks of AKBNK, EKGYO, EREGL, GARAN, HALKB, ISCTR, KCHOL, SAHOL, THYAO, TTKOM, TUPRS, VAKBN and YKBNK stocks (Deutsche Bank, 2016). IS Investment has been issuing covered warrants based on AKBNK, EKGYO, EREGL, GARAN, HALKB, ISCTR, KCHOL, SAHOL, SISE, THYAO, TOASO, TTKOM, TUPRS, VAKBN and YKBNK stocks, BIST 30 and DAX ${ }^{\circledR}$ indexes, ons gold, Brent oil, USD/TL 
and EUR/USD exchanges. Also IS Investment has been issuing also flexo exchange, flexo oil, flexo gold and flexo DAX warrants (Is Warrant, 2016). The underlying asset of covered warrants of Garanti Bank that has started to issue covered warrants in 2013 is BIST 30 indexes (Garanti Bank, 2016).

\section{Warrant Pricing Models}

Option pricing models are used to price warrants. There are several models to predict warrant price, but there is no model to set an exact price for warrants (Boonchuaymetta \& Kongtoranin, 2007: 57). Black-Scholes model that is the most popular option pricing model and Gram-Charlier model that allows for skewness and greater kurtosis than the normal distribution are reviewed in this section because these models are used to price covered warrants in this study.

\subsection{Black - Scholes Pricing Model}

Black-Scholes model is hailed as a milestone in derivative trading, and elaborates hedging strategies which provide investors with a safe growth of appropriately composed portfolios of financial assets. The usefulness of the Black-Scholes formula was based on several assumptions (Kleinert \& Korbel, 2016: 1). The model assumes ideal conditions in the market (Black \& Scholes, 1973: 640):

- The short-term interest rate is known and is constant through time.

- The stock price follows a random walk in continuous time with a variance rate proportional to the square of the stock price. Thus the distribution of possible stock prices at the end of any finite interval is log-normal. The variance rate of the return on the stock is constant.

- The stock pays no dividends or other distributions.

- The option is "European", that is, it can only be exercised at maturity.

- There are no transaction costs in buying or selling the stock or the option.

- It is possible to borrow any fraction of the price of a security to buy it or to hold it, at the short-term interest rate.

- There are no penalties to short selling. A seller who does not own a security will simply accept the price of the security from a buyer, and will agree to settle with the buyer on some future date by paying him an amount equal to the price of the security on that date.

Every aspect of the market cannot be considered in any given model, as every factor affecting the price of a financial security cannot be captured mathematically. Despite of these assumptions, the Black-Scholes formula remains in wide spread use and despite its harshest critics a formula that is still integral to options pricing can hardly be called "dead" or "dying" (Yalincak, 2005: 2-9). 
The Black-Scholes model for put and call warrants is demonstrated below (Higham, 2004: 80-81).

\section{Pricing model for call warrants;}

$$
\mathrm{C}=\mathrm{SN}\left(\mathrm{d}_{1}\right)-\mathrm{Ke}^{-\mathrm{rt}} \mathrm{N}\left(\mathrm{d}_{2}\right)
$$

\section{Pricing model for put warrants;}

$$
\mathrm{P}=\mathrm{Ke} \mathrm{-rt}^{\mathrm{rt}}\left(-\mathrm{d}_{2}\right)-\mathrm{SN}\left(-\mathrm{d}_{1}\right)
$$

The variables of Black-Scholes formula are explained below (Higham, 2004: 80; Chambers, 2012: 113).

$\mathrm{d}_{1}$

$$
\begin{array}{ll}
=\frac{1}{\sigma \sqrt{\tau}}\left[\ln \left(\frac{S}{K}\right)+\left(r+\frac{\sigma^{2}}{2}\right) \tau\right] & \\
=\frac{1}{\sigma \sqrt{\tau}}\left[\ln \left(\frac{S}{K}\right)+\left(r-\frac{\sigma^{2}}{2}\right) \tau\right] & =d_{1}-\sigma \sqrt{\tau}
\end{array}
$$

$=$ underlying stock price

K

$=$ warrant exercise price

$\mathrm{R}$

$=$ annual risk free rate of interest

$\sigma$

$=$ annual standard deviation of logarithmic return of stocks

$\tau$

$=$ remaining days to maturity

$\mathrm{N}(\mathrm{x})$

$=$ cumulative standard normal distribution function

$=\mathrm{N}(0,1)$ cumulative probability distribution function

$\ln$

$=$ natural logarithm

$\mathrm{e}$

$=$ mathematical constant $(2.7183)$

\subsection{Gram - Charlier Pricing Model}

Gram-Charlier model is developed by Backus, Foresi, and Wu (2004) and accounts both skewness and kurtosis of returns of the underlying asset. They use a Gram-Charlier expansion up to the fourth order in the distribution of returns of the underlying asset. This allows for skewness and greater kurtosis than the normal distribution to be introduced into 
option pricing. This model, however, assumes that volatility is constant over time (Rouah \& Vainberg, 2007: 124).

The pricing formula and variables of Gram-Charlier model are demonstrated below (Straja, 2003: 2; Rouah \& Vainberg, 2007: 126).

$$
\begin{aligned}
& C=S e^{-\delta \tau-\sigma^{3} \tau^{\frac{3}{2}} \frac{\gamma_{1}}{6}-\sigma^{4} \tau^{2} \frac{\gamma_{2}}{24}} N(d)-K e^{-r \tau} N(d-\sigma \sqrt{\tau}) \\
& +S e^{-\delta \tau} \sigma \sqrt{\tau} \varphi(d)\left\{(2 \sigma \sqrt{\tau}-d) \frac{\gamma_{1}}{6}+\left[3 \sigma^{2} \tau-3 \sigma \sqrt{\tau} d+d^{2}-1\right] \frac{\gamma_{2}}{24}\right\} \\
& +S e^{-\delta \tau-\sigma^{3} \tau^{\frac{3}{2}} \frac{\gamma_{1}}{6}-\sigma^{4} \tau^{2} \frac{\gamma_{2}}{24}} \cdot\left[\sigma^{3} \tau^{\frac{3}{2}} \frac{\gamma_{1}}{6}+\sigma^{4} \tau^{2} \frac{\gamma_{2}}{24}\right] N(d) \\
& \text { d } \\
& =\frac{\left[\ln \left(\frac{S}{K}\right)+(r-\delta) \tau+\frac{\sigma^{2} \tau}{2}-\sigma^{3} \tau^{3 / 2} \frac{\gamma_{1}}{6}-\sigma^{4} \tau^{2} \frac{\gamma_{2}}{24}\right]}{\sigma \sqrt{\tau}} \\
& \mathrm{S} \quad=\text { underlying stock price } \\
& \mathrm{K} \quad \text { = warrant exercise price } \\
& \mathrm{r} \quad=\text { annual risk free rate of interest } \\
& \sigma \quad=\text { annual standard deviation of logarithmic return of stocks } \\
& \tau=\text { = remaining days to maturity } \\
& \begin{array}{ll}
\mathrm{N}(\mathrm{x}) & =\text { cumulative standard normal distribution function } \\
& =\mathrm{N}(0,1) \text { cumulative probability distribution function }
\end{array} \\
& \phi \quad=\text { normal probability distribution function } \\
& \delta \quad=\text { dividend yield } \\
& \gamma 1=\text { skewness of underlying stocks' return } \\
& \gamma 2=\text { kurtosis of underlying stocks' return }
\end{aligned}
$$

\section{Literature Review}

The World Federation of Exchanges has divided exchanges of world into three groups; exchanges of Asia and Pacific, Europe, Africa and Middle East, and America. Exchanges' trading volume of warrants is illustrated in Figure 4 and 5. Literature is reviewed 
under two categories; Asia-Pasific countries and Europe-Africa and Middle East countries, because there is no more warrants traded in America.

Figure: 4

Transaction Volume of Structured Products in 2014

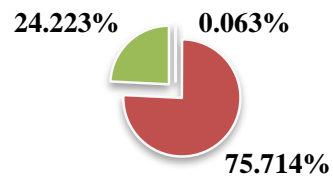

- Amerika

- Asya-Pasifik

- Avrupa - Afrika - Orta Doğu

Figure: 5

Transaction Volume of Structured Products in 2015

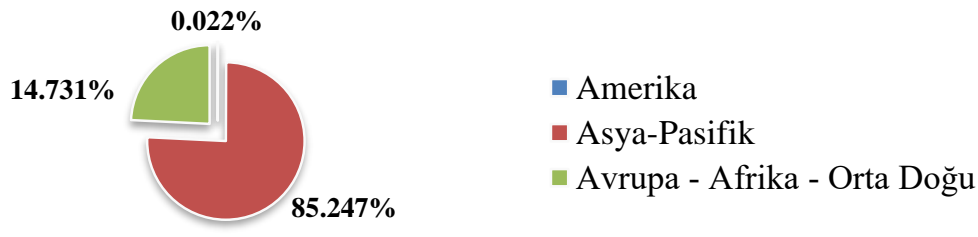

\subsection{Literature Review of Asia and Pacific Countries on Covered Warrants}

Exchanges of Asia and Pacific countries are more familiar with structured products like warrants, as seen from the figures above, so there are more studies about pricing covered warrants in Asia and Pacific literature.

Hong Kong Exchange is the most significant and biggest exchange about warrants trade. Duan and Yan (1999) price covered warrants traded on the Hong Kong Exchange and based on HSBC stocks for before and after of 1997 crisis. The result of their study presents that the models have priced warrants lower than the market. Wu, Ma and Wang (2012) use GARCH diffusion and Black-Scholes model to price Hang Seng Index warrants traded on the Hong Kong Stock Exchange. Empirical results show that the GARCH diffusion model outperforms the Black-Scholes model in terms of the pricing accuracy, indicating that the pricing model incorporated with stochastic volatility can improve the pricing of warrants.

Exchanges of Taiwan is also significant for covered warrants. Chen and Huang (2002), and Chen (2003) price covered warrants traded on Exchanges of Taiwan that is one of the significant exchanges of the Asia and Pacific region. Chen and Huang have used HullWhite and Black-Scholes models to price covered warrants and attained similar results with Duan and Yan. Another result of the study of Chen and Huang is that models which include implied or stochastic volatility are more powerful to predict the price of warrants. Chen has priced 23 covered warrants traded in Taiwan by using Black-Scholes and Klein model that 
is incorporated with credit risk, and reported that when credit risk included in warrant pricing, price of warrant will be lower than Black-Scholes model price.

Pricing of covered warrants has attracted a great deal of attention in China. Fan and Yuan (2011) price 10 covered and 7 equity warrants traded in warrants market in China and find that the observed market prices are irrationally higher than the Black-Scholes model prices by $80.38 \%$ (using 180-day historical volatility) and $140.50 \%$ (using EGARCH volatility). The study of Liu and Rangan (2012) examines the pricing covered warrants traded in China and finds that the implied volatility is higher than the realized volatility across maturities, resulting in huge overvaluation across maturities. The results appear to be overvalued covered warrants and inefficient markets.

Bursa Malaysia has a huge variety of financial products. Mansor and Jaffar (2014) price covered warrants traded in Bursa Malaysia by using finite difference approach and central in time and central in space scheme (CTCS). Their study reveals that CTCS scheme gives closed prices to market prices.

\subsection{Literature Review of Europe-Africa and Middle East Countries on Covered Warrants}

The exchanges of the United Kingdom, Greece, and Turkey are among Europe-Africa and Middle East exchanges.

Klinpratoom (2010) studies on covered warrants pricing in the United Kingdom and uses Black-Scholes model and Klein model that is incorporated with credit risk. She explores that covered warrants are overvalued in the market of the United Kingdom, and Klein model gives lower prices than Black-Scholes model. Siriopoulos and Fassas (2014) attempts to price covered warrants in Exchange of Athens. The results of their study show that covered warrants are undervalued in market. Akmehmet (2012) prices covered warrants based on stocks of several companies and BIST-30 index by using Black-Scholes model and different volatilities and interest rate parameters. The model that is incorporated Central Bank Republic of Turkey's policy interest rate and 90 day volatility data has the highest capacity to forecast market prices. Karakuş and Zor (2014) examines 61 covered warrants based on BIST-30 index by using Black-Scholes, Black-Scholes-Merton, Binomial, and Square Root Constant Elasticity Variance models. As a result of their study, Black- Scholes-Merton model is the most efficient pricing model for in-the-money warrants, but it is not possible to choose any model for at-the-money and out-of-money warrants.

\section{Data and Methodology}

This study attempts to price 25 call and 25 put covered warrants based on stocks of Eregli Demir ve Celik Fabrikaları T.A.S., issued by IS Investment by using Black-Scholes and Gram-Charlier models. The research group covers covered warrants that are issued and expired between January, 2015 and December, 2015. In line with the study of Chen and Liao 
Aksu, M. \& Ş. Sakarya (2018), "Pricing of Covered Warrants: An

Analysis on Borsa İstanbul", Sosyoekonomi, Vol. 26(37), 201-218.

(2010), butterfly warrants ${ }^{3}$ are excluded from research group and so final research group consists of 23 call and 23 put warrants. Table 1 provides a complete list of research group. The covered warrants that have codes of ERIDB, ERIDC, ERIVV and ERIVY are excluded research group because of their butterfly character. The covered warrants have the " 0 " value on some days and warrants that are traded till maturity have no value at the end of the maturity, so " 0 " days and the last day of maturities are excluded from analysis.

Table: 1

\section{The Research Group}

\begin{tabular}{|c|c|c|c|c|c|c|}
\hline Type of Warrants & Codes of Warrants & Underlying Asset & Issuer & Date of Issuance & Expiry Date & Trading Days \\
\hline Call & ERIBO & Eregli Stocks & IS Investment & 14.01 .2015 & 30.04 .2015 & 75 \\
\hline Call & ERICA & Eregli Stocks & IS Investment & 14.01 .2015 & 30.04 .2015 & 72 \\
\hline Call & ERICB & Eregli Stocks & IS Investment & 14.01 .2015 & 30.04 .2015 & 67 \\
\hline Call & ERICC & Eregli Stocks & IS Investment & 18.03 .2015 & 29.05 .2015 & 48 \\
\hline Call & ERICD & Eregli Stocks & IS Investment & 18.03 .2015 & 29.05 .2015 & 46 \\
\hline Call & ERICE & Eregli Stocks & IS Investment & 18.03 .2015 & 29.05 .2015 & 47 \\
\hline Call & ERICF & Eregli Stocks & IS Investment & 09.04 .2015 & 30.06 .2015 & 51 \\
\hline Call & ERICG & Eregli Stocks & IS Investment & 09.04 .2015 & 30.06 .2015 & 52 \\
\hline Call & ERICH & Eregli Stocks & IS Investment & 09.04.2015 & 30.06 .2015 & 54 \\
\hline Call & ERICI & Eregli Stocks & IS Investment & 12.05 .2015 & 31.07 .2015 & 49 \\
\hline Call & ERICJ & Eregli Stocks & IS Investment & 12.05 .2015 & 31.07 .2015 & 42 \\
\hline Call & ERICK & Eregli Stocks & IS Investment & 12.05 .2015 & 31.08 .2015 & 53 \\
\hline Call & ERICL & Eregli Stocks & IS Investment & 26.05 .2015 & 31.07 .2015 & 40 \\
\hline Call & ERICM & Eregli Stocks & IS Investment & 16.06 .2015 & 31.08 .2015 & 43 \\
\hline Call & ERICN & Eregli Stocks & IS Investment & 16.06 .2015 & 31.08 .2015 & 38 \\
\hline Call & ERIDA & Eregli Stocks & IS Investment & 16.06.2015 & 30.09 .2015 & 48 \\
\hline Call & ERIDB & Eregli Stocks & IS Investment & 02.07 .2015 & 30.09 .2015 & butterfly \\
\hline Call & ERIDC & Eregli Stocks & IS Investment & 02.07 .2015 & 30.09 .2015 & butterfly \\
\hline Call & ERIDD & Eregli Stocks & IS Investment & 02.07 .2015 & 30.10 .2015 & 40 \\
\hline Call & ERIDE & Eregli Stocks & IS Investment & 24.08 .2015 & 30.10 .2015 & 46 \\
\hline Call & ERIDF & Eregli Stocks & IS Investment & 24.08 .2015 & 30.10 .2015 & 46 \\
\hline Call & ERIDG & Eregli Stocks & IS Investment & 24.08 .2015 & 30.10 .2015 & 39 \\
\hline Call & ERIDH & Eregli Stocks & IS Investment & 10.09 .2015 & 30.11 .2015 & 54 \\
\hline Call & ERIDI & Eregli Stocks & IS Investment & 10.09 .2015 & 30.11 .2015 & 53 \\
\hline Call & ERIDJ & Eregli Stocks & IS Investment & 10.09 .2015 & 30.11 .2015 & 49 \\
\hline Put & ERITV & Eregli Stocks & IS Investment & 14.01 .2015 & 30.04 .2015 & 73 \\
\hline Put & ERITY & Eregli Stocks & IS Investment & 14.01 .2015 & 30.04 .2015 & 73 \\
\hline Put & ERITZ & Eregli Stocks & IS Investment & 14.01 .2015 & 30.04 .2015 & 70 \\
\hline Put & ERIUP & Eregli Stocks & IS Investment & 18.03.2015 & 29.05 .2015 & 24 \\
\hline Put & ERIUR & Eregli Stocks & IS Investment & 18.03 .2015 & 29.05 .2015 & 16 \\
\hline Put & ERIUS & Eregli Stocks & IS Investment & 18.03 .2015 & 29.05 .2015 & 16 \\
\hline Put & ERIUT & Eregli Stocks & IS Investment & 09.04 .2015 & 30.06 .2015 & 53 \\
\hline Put & ERIUU & Eregli Stocks & IS Investment & 09.04 .2015 & 30.06 .2015 & 46 \\
\hline Put & ERIUV & Eregli Stocks & IS Investment & 09.04.2015 & 30.06 .2015 & 43 \\
\hline Put & ERIUY & Eregli Stocks & IS Investment & 12.05 .2015 & 31.07 .2015 & 55 \\
\hline Put & ERIUZ & Eregli Stocks & IS Investment & 12.05 .2015 & 31.07 .2015 & 40 \\
\hline Put & ERIVP & Eregli Stocks & IS Investment & 12.05 .2015 & 31.08 .2015 & 73 \\
\hline Put & ERIVR & Eregli Stocks & IS Investment & 26.05 .2015 & 31.07 .2015 & 45 \\
\hline Put & ERIVS & Eregli Stocks & IS Investment & 16.06 .2015 & 31.08 .2015 & 52 \\
\hline Put & ERIVT & Eregli Stocks & IS Investment & 16.06 .2015 & 31.08 .2015 & 46 \\
\hline Put & ERIVU & Eregli Stocks & IS Investment & 16.06 .2015 & 30.09 .2015 & 71 \\
\hline Put & ERIVV & Eregli Stocks & IS Investment & 02.07 .2015 & 30.09 .2015 & butterfly \\
\hline Put & ERIVY & Eregli Stocks & IS Investment & 02.07 .2015 & 30.09 .2015 & butterfly \\
\hline Put & ERIVZ & Eregli Stocks & IS Investment & 02.07 .2015 & 30.10 .2015 & 79 \\
\hline Put & ERIYP & Eregli Stocks & IS Investment & 24.08 .2015 & 30.10 .2015 & 46 \\
\hline Put & ERIYR & Eregli Stocks & IS Investment & 24.08 .2015 & 30.10 .2015 & 36 \\
\hline Put & ERIYS & Eregli Stocks & IS Investment & 24.08 .2015 & 30.10 .2015 & 31 \\
\hline Put & ERIYT & Eregli Stocks & IS Investment & 10.09 .2015 & 30.11 .2015 & 54 \\
\hline
\end{tabular}

3 Butterfly warrants are warrants that issued several issuers (Deutsche Bank and IS Investment) based on same underlying security and have same maturity. 


\begin{tabular}{|l|l|l|l|l|l|l|}
\hline Put & ERIYU & Eregli Stocks & IS Investment & 10.09 .2015 & 30.11 .2015 & 50 \\
\hline Put & ERIYV & Eregli Stocks & IS Investment & 10.09 .2015 & 30.11 .2015 & 35 \\
\hline
\end{tabular}

The data set of this study includes variables of Black-Scholes and Gram-Charlier models; strike prices of covered warrants, daily closing prices of Eregli stocks, risk free rate of interest, dividend yield of stocks, volatility, skewness and kurtosis of logarithmic return of stocks and the maturity of covered warrants. To evaluate the pricing capacity of models, daily closing prices of covered warrants are needed. The sources and programs that are used to obtain data are presented on Table 2 .

Table: 2

Sources of Data

\begin{tabular}{|l|l|}
\hline Strike prices of covered warrants & CSD \\
\hline The maturity of covered warrants & CSD \\
\hline Daily closing prices of covered warrants & Finnet 2000+ \\
\hline Daily closing prices of Eregli stocks (unadjusted prices) & BIST Data Store \\
\hline The risk free rate of interest & CBRT \\
\hline The dividend yield of Eregli stocks & Finnet \\
\hline The daily volatility of logarithmic return of Eregli stocks & Numbers \\
\hline The skewness and kurtosis of logarithmic return of Eregli stocks & SPSS \\
\hline CSD. Central Securities Depository of Turkey:CBRT: Central Bank Republic of Turkey.
\end{tabular}

*CSD: Central Securities Depository of Turkey; CBRT: Central Bank Republic of Turkey.

The variables of risk free rate of interest, dividend yield of stocks, and volatility of logarithmic return of stocks are not exactly definite or observable variables so they should be assumed. The interest rate of the treasury bills and government bonds sold by auction is used as the risk free rate of interest. The annual simple average interest rate of the bills and bonds that have the shortest maturity is used, because warrants have no longer maturity in Turkey. The dividend yield of Eregli stocks is calculated as average of 5-year period (20102014), because covered warrants have become to issue in 2010 and this study examines covered warrants of 2015.21-day historical volatility is used to predict the volatility, because the maturity of covered warrants traded on BIST is no longer, and 21-day is one of the period that is used by BIST to gauge volatility. Daily volatility is calculated over the maturity of covered warrants. Morever, the unadjusted daily closing prices of Eregli stocks are used to price warrants. The variables are demonstrated on Table 3.

Table: 3

\section{The Variables of Models}

\begin{tabular}{|c|c|c|c|c|c|c|c|c|}
\hline $\begin{array}{c}\text { Types of } \\
\text { Warrants }\end{array}$ & $\begin{array}{c}\text { Codes of } \\
\text { Warrants } \\
\end{array}$ & $\begin{array}{c}\text { Date of } \\
\text { Issuance }\end{array}$ & $\begin{array}{c}\text { Expiry } \\
\text { Date }\end{array}$ & $\begin{array}{c}\text { Risk Free } \\
\text { Interest Rate }(\%)\end{array}$ & $\begin{array}{c}\text { Strike } \\
\text { Prices (f) } \\
\end{array}$ & Skewness & Kurtosis & $\begin{array}{c}\text { Dividend } \\
\text { Yield }\end{array}$ \\
\hline Call & ERIBO & 14.01 .2015 & 30.04 .2015 & 7.75 & 4.5 & -0.667 & 0.493 & 0.0598 \\
\hline Call & ERICA & 14.01 .2015 & 30.04 .2015 & 7.75 & 5 & -0.667 & 0.493 & 0.0598 \\
\hline Call & ERICB & 14.01 .2015 & 30.04 .2015 & 7.75 & 5.2 & -0.667 & 0.493 & 0.0598 \\
\hline Call & ERICC & 18.03 .2015 & 29.05 .2015 & 8.08 & 3.75 & -3.201 & 16.189 & 0.0598 \\
\hline Call & ERICD & 18.03 .2015 & 29.05 .2015 & 8.08 & 4 & -3.201 & 16.189 & 0.0598 \\
\hline Call & ERICE & 18.03 .2015 & 29.05 .2015 & 8.08 & 4.2 & -3.201 & 16.189 & 0.0598 \\
\hline Call & ERICF & 09.04 .2015 & 30.06 .2015 & 9.1 & 3.9 & -2.579 & 12.661 & 0.0598 \\
\hline Call & ERICG & 09.04 .2015 & 30.06 .2015 & 9.1 & 4.1 & -2.579 & 12.661 & 0.0598 \\
\hline Call & ERICH & 09.04 .2015 & 30.06 .2015 & 9.1 & 4.4 & -2.579 & 12.661 & 0.0598 \\
\hline Call & ERICI & 12.05 .2015 & 31.07 .2015 & 9.69 & 4.55 & -2.021 & 9.397 & 0.0598 \\
\hline Call & ERICJ & 12.05 .2015 & 31.07 .2015 & 9.69 & 4.75 & -2.021 & 9.397 & 0.0598 \\
\hline Call & ERICK & 12.05 .2015 & 31.08 .2015 & 9.69 & 4.9 & -1.366 & 6.837 & 0.0598 \\
\hline Call & ERICL & 26.05 .2015 & 31.07 .2015 & 9.69 & 4.3 & -1.855 & 7.935 & 0.0598 \\
\hline Call & ERICM & 16.06 .2015 & 31.08 .2015 & 9.85 & 4.4 & 0.220 & -0.091 & 0.0598 \\
\hline Call & ERICN & 16.06 .2015 & 31.08 .2015 & 9.85 & 4.6 & 0.220 & -0.091 & 0.0598 \\
\hline Call & ERIDA & 16.06 .2015 & 30.09 .2015 & 9.85 & 4.75 & 0.189 & -0.264 & 0.0598 \\
\hline Call & ERIDD & 02.07 .2015 & 30.10 .2015 & 9.52 & 5 & 0.138 & -0.111 & 0.0598 \\
\hline
\end{tabular}


Aksu, M. \& Ş. Sakarya (2018), "Pricing of Covered Warrants: An

Analysis on Borsa İstanbul", Sosyoekonomi, Vol. 26(37), 201-218.

\begin{tabular}{|c|c|c|c|c|c|c|c|c|}
\hline Call & ERIDE & 24.08 .2015 & 30.10 .2015 & 11.02 & 3.6 & -0.107 & -0.331 & 0.0598 \\
\hline Call & ERIDF & 24.08 .2015 & 30.10 .2015 & 11.02 & 4 & -0.107 & -0.331 & 0.0598 \\
\hline Call & ERIDG & 24.08 .2015 & 30.10 .2015 & 11.02 & 4.4 & -0.107 & -0.331 & 0.0598 \\
\hline Call & ERIDH & 10.09 .2015 & 30.11 .2015 & 11.03 & 3.5 & -0.634 & 0.667 & 0.0598 \\
\hline Call & ERIDI & 10.09 .2015 & 30.11 .2015 & 11.03 & 3.9 & -0.634 & 0.667 & 0.0598 \\
\hline Call & ERIDJ & 10.09 .2015 & 30.11 .2015 & 11.03 & 4.1 & -0.634 & 0.667 & 0.0598 \\
\hline Put & ERITV & 14.01 .2015 & 30.04 .2015 & 7.75 & 5 & -0.667 & 0.493 & 0.0598 \\
\hline Put & ERITY & 14.01 .2015 & 30.04 .2015 & 7.75 & 4.5 & -0.667 & 0.493 & 0.0598 \\
\hline Put & ERITZ & 14.01 .2015 & 30.04 .2015 & 7.75 & 4.2 & -0.667 & 0.493 & 0.0598 \\
\hline Put & ERIUP & 18.03 .2015 & 29.05 .2015 & 8.08 & 3.4 & -3.201 & 16.189 & 0.0598 \\
\hline Put & ERIUR & 18.03 .2015 & 29.05 .2015 & 808 & 3.2 & -3.201 & 16.189 & 0.0598 \\
\hline Put & ERIUS & 18.03 .2015 & 29.05 .2015 & 8.08 & 3 & -3.201 & 16.189 & 0.0598 \\
\hline Put & ERIUT & 09.04 .2015 & 30.06 .2015 & 9.1 & 4.1 & -2.579 & 12.661 & 0.0598 \\
\hline Put & ERIUU & 09.04 .2015 & 30.06 .2015 & 9.1 & 3.9 & -2.579 & 12.661 & 0.0598 \\
\hline Put & ERIUV & 09.04 .2015 & 30.06 .2015 & 9.1 & 3.7 & -2.579 & 12.661 & 0.0598 \\
\hline Put & ERIUY & 12.05 .2015 & 31.07 .2015 & 9.69 & 4.3 & -2.021 & 9.397 & 0.0598 \\
\hline Put & ERIUZ & 12.05 .2015 & 31.07 .2015 & 9.69 & 4.1 & -2.021 & 9.397 & 0.0598 \\
\hline Put & ERIVP & 12.05 .2015 & 31.08 .2015 & 9.69 & 4 & -1.366 & 6.837 & 0.0598 \\
\hline Put & ERIVR & 26.05 .2015 & 31.07 .2015 & 9.69 & 4.6 & -1.855 & 7.935 & 0.0598 \\
\hline Put & ERIVS & 16.06 .2015 & 31.08 .2015 & 9.85 & 4.4 & 0.220 & -0.091 & 0.0598 \\
\hline Put & ERIVT & 16.06 .2015 & 31.08 .2015 & 9.85 & 4.2 & 0.220 & -0.091 & 0.0598 \\
\hline Put & ERIVU & 16.06 .2015 & 30.09 .2015 & 9.85 & 4 & 0.189 & -0.264 & 0.0598 \\
\hline Put & ERIVZ & 02.07 .2015 & 30.10 .2015 & 9.52 & 4 & 0.138 & -0.111 & 0.0598 \\
\hline Put & ERIYP & 24.08 .2015 & 30.10 .2015 & 11.02 & 4.2 & -0.107 & -0.331 & 0.0598 \\
\hline Put & ERIYR & 24.08 .2015 & 30.10 .2015 & 11.02 & 3.6 & -0.107 & -0.331 & 0.0598 \\
\hline Put & ERIYS & 24.08 .2015 & 30.10 .2015 & 11.02 & 3.4 & -0.107 & -0.331 & 0.0598 \\
\hline Put & ERIYT & 10.09 .2015 & 30.11 .2015 & 11.03 & 3.9 & -0.634 & 0.667 & 0.0598 \\
\hline Put & ERIYU & 10.09 .2015 & 30.11 .2015 & 11.03 & 3.5 & -0.634 & 0.667 & 0.0598 \\
\hline Put & ERIYV & 10.09 .2015 & 30.11 .2015 & 11.03 & 3.3 & -0.634 & 0.667 & 0.0598 \\
\hline
\end{tabular}

\section{Empirical Results}

Table 4 reveals average market, Black-Scholes and Gram-Charlier model prices of covered warrants.

Table: 4

Average Market, Black-Scholes and Gram-Charlier Prices of Covered Warrants

\begin{tabular}{|c|c|c|c|c|}
\hline Codes of Warrants & Type of Warrants & Market & Black-Scholes & Gram-Charlier \\
\hline ERIBO & Call & 0.1932 & 0.1573 & 0.1275 \\
\hline ERICA & Call & 0.1549 & 0.0560 & 0.0298 \\
\hline ERICB & Call & 0.1157 & 0.0406 & 0.0156 \\
\hline ERICC & Call & 11.528 & 0.7526 & 0.9214 \\
\hline ERICD & Call & 0.8004 & 0.5393 & 0.6275 \\
\hline ERICE & Call & 0.5548 & 0.3684 & 0.3859 \\
\hline ERICF & Call & 10.342 & 0.6698 & 0.8064 \\
\hline ERICG & Call & 0.7114 & 0.4917 & 0.5286 \\
\hline ERICH & Call & 0.3581 & 0.2698 & 0.1656 \\
\hline ERICI & Call & 0.1654 & 0.1978 & 0.1066 \\
\hline ERICJ & Call & 0.1063 & 0.1465 & 0.0417 \\
\hline ERICK & Call & 0.1009 & 0.1384 & 0.0680 \\
\hline ERICL & Call & 0.2169 & 0.2213 & 0.1216 \\
\hline ERICM & Call & 0.1463 & 0.1249 & 0.1182 \\
\hline ERICN & Call & 0.0947 & 0.0883 & 0.0862 \\
\hline ERIDA & Call & 0.0873 & \begin{tabular}{|l|}
0.0830 \\
\end{tabular} & 0.0808 \\
\hline ERIDD & Call & 0.0435 & 0.0256 & 0.0372 \\
\hline ERIDE & Call & 0.3671 & 0.3616 & 0.3466 \\
\hline ERIDF & Call & 0.1089 & 0.1117 & 0.1037 \\
\hline ERIDG & Call & 0.0264 & 0.0276 & 0.0151 \\
\hline ERIDH & Call & 0.4860 & 0.4687 & 0.4721 \\
\hline ERIDI & Call & 0.2055 & 0.1860 & 0.1655 \\
\hline ERIDJ & Call & 0.1298 & 0.1133 & 0.0859 \\
\hline ERITV & Put & 13.892 & 0.6762 & 0.6891 \\
\hline ERITY & Put & 0.6476 & 0.2846 & 0.2925 \\
\hline ERITZ & Put & 0.3626 & 0.1356 & 0.1481 \\
\hline ERIUP & Put & 0.0582 & 0.0029 & 0.5267 \\
\hline ERIUR & Put & 0.0331 & 0.0009 & 10.199 \\
\hline ERIUS & Put & 0.0238 & 0.0002 & 12.544 \\
\hline ERIUT & Put & 0.1891 & 0.0448 & 0.1077 \\
\hline
\end{tabular}




\begin{tabular}{|c|c|c|c|c|}
\hline ERIUU & Put & 0.0381 & 0.0218 & 0.1847 \\
\hline ERIUV & Put & 0.0108 & 0.0085 & 0.2968 \\
\hline ERIUY & Put & 0.1581 & $\mathbf{0 . 1 7 7 1}$ & 0.1365 \\
\hline ERIUZ & Put & 0.0713 & $\mathbf{0 . 1 0 0 9}$ & 0.0371 \\
\hline ERIVP & Put & 0.1240 & $\mathbf{0 . 1 2 4 1}$ & 0.0834 \\
\hline ERIVR & Put & 0.3585 & $\mathbf{0 . 4 0 8 7}$ & 0.4012 \\
\hline ERIVS & Put & 0.3631 & 0.3520 & 0.3714 \\
\hline ERIVT & Put & 0.2333 & 0.2230 & 0.2370 \\
\hline ERIVU & Put & 0.1880 & 0.1735 & 0.1889 \\
\hline ERIVZ & Put & 0.2154 & 0.1858 & 0.2057 \\
\hline ERIYP & Put & 0.3378 & 0.3307 & 0.0678 \\
\hline ERIYR & Put & 0.0692 & 0.0579 & 0.0356 \\
\hline ERIYS & Put & 0.0377 & 0.0272 & 0.1388 \\
\hline ERIYT & Put & 0.0408 & 0.1339 & 0.0534 \\
\hline ERIYV & Put & 0.0306 & 0.0226 & 0.0109 \\
\hline
\end{tabular}

Black-Scholes model gives higher prices than Gram-Charlier model for 16 call warrants (bold), and Gram-Charlier provides higher prices than Black-Scholes for put warrants. Table 5 compares average market prices and model prices and presents that BlackScholes underprices 17 call and 19 put warrants while overprices only 6 call and 4 put warrants and Gram-Charlier underprices all call and 11 put warrants while overprices only 12 put warrants. The result is that these models show a tendency to underprice covered warrants, only Gram-Charlier model has a tendency to overprice put warrants.

Table: 5

Numbers of Warrants Accurately Priced By Models

\begin{tabular}{|c|c|c|c|}
\hline For Call Warrants & Warrants & For Put Warrants & Warrants \\
\hline BS $<$ Market & 17 & BS $<$ Market & 19 \\
\hline BS $>$ Market & 6 & BS $>$ Market & 4 \\
\hline GC $<$ Market & 23 & GC $<$ Market & 11 \\
\hline GC $>$ Market & 0 & GC $>$ Market & 12 \\
\hline
\end{tabular}

The price deviations of models from the market prices are presented on Table 6. Table 6 shows that Black-Scholes model underprices average $21.82 \%$ call warrants while GramCharlier underprices $36.53 \%$. Black-Scholes still underprices average $31.88 \%$ put warrants and Gram-Charlier overprices $22.71 \%$.

Table: 6

Average Model Pricing Error of Warrants

\begin{tabular}{|c|c|c|c|c|c|c|c|}
\hline & & BS-Market & GC-Market & & & BS-Market & GC-Market \\
\hline Codes of Warrants & Types of Warrants & $\mu$ & $\mu$ & Codes of Warrants & Types of Warrants & $\mu$ & $\mu$ \\
\hline ERIBO & Call & -0.6654 & -0.7555 & ERITV & Put & -0.5158 & -0.5049 \\
\hline ERICA & Call & -0.7931 & -1.2600 & ERITY & Put & -0.5870 & -0.5731 \\
\hline ERICB & Call & -0.8079 & -1.3958 & ERITZ & Put & -0.6671 & -0.6201 \\
\hline ERICC & Call & -0.3161 & -0.2019 & ERIUP & Put & -0.9726 & $28.5897 *$ \\
\hline ERICD & Call & -0.2979 & -0.2320 & ERIUR & Put & -0.9852 & 71.6176* \\
\hline ERICE & Call & -0.3273 & -0.3586 & ERIUS & Put & -0.9956 & $100.4754 *$ \\
\hline ERICF & Call & -0.3481 & -0.2311 & ERIUT & Put & -0.4243 & 0.7498 \\
\hline ERICG & Call & -0.3051 & -0.2788 & ERIUU & Put & -0.4045 & 2.1812 \\
\hline ERICH & Call & -0.2541 & -0.6195 & ERIUV & Put & -0.5171 & 7.9013* \\
\hline ERICI & Call & -0.0437 & -0.5404 & ERIUY & Put & 0.1900 & -0.1203 \\
\hline ERICJ & Call & 0.1683 & -0.6758 & ERIUZ & Put & 0.5642 & -0.4393 \\
\hline ERICK & Call & 0.0933 & -0.1564 & ERIVP & Put & 0.0772 & -0.3292 \\
\hline ERICL & Call & -0.1543 & -0.5818 & ERIVR & Put & 0.1850 & 0.1431 \\
\hline ERICM & Call & -0.1839 & -0.1568 & ERIVS & Put & -0.0262 & 0.0389 \\
\hline ERICN & Call & -0.2767 & -0.1805 & ERIVT & Put & -0.0360 & 0.0380 \\
\hline ERIDA & Call & -0.0612 & 0.0871 & ERIVU & Put & -0.0938 & -0.0038 \\
\hline ERIDD & Call & 0.0097 & 0.7632 & ERIVZ & Put & -0.1694 & -0.0812 \\
\hline ERIDE & Call & -0.0236 & -0.0668 & ERIYP & Put & -0.0304 & 0.0037 \\
\hline ERIDF & Call & 0.0053 & -0.0699 & ERIYR & Put & -0.2603 & -0.1214 \\
\hline
\end{tabular}




\begin{tabular}{|c|c|c|c|c|c|c|c|}
\hline ERIDG & Call & -0.0399 & -0.7447 & ERIYS & Put & -0.3606 & -0.1424 \\
\hline ERIDH & Call & -0.0400 & -0.0323 & ERIYT & Put & -0.1371 & -0.0862 \\
\hline ERIDI & Call & -0.1730 & -0.2810 & ERIYU & Put & -0.4859 & 1.1682 \\
\hline ERIDJ & Call & -0.1845 & -0.4325 & ERIYV & Put & -0.6789 & 3.0142 \\
\hline Average & Call & -0.2182 & -0.3653 & Average & Put & -0.3188 & 0.2271 \\
\hline
\end{tabular}

*These price differences are ignored because of probable misleading effect on average price differences.

This study is to explore whether Black-Scholes and Gram-Charlier models provide accurate price for days which in warrants are in-the-money or out-of-the-money. Price differences of models from the market are seperated according to warrants moneyness. There are several formulas to calculate moneyness factor in literature, but in this study moneyness is determined by comparing underlying stocks' prices and strike prices of warrants.

Table: 7

The Pricing Differences of Models from the Market According to Moneyness of Call Warrants

\begin{tabular}{|c|c|c|c|c|}
\hline Codes of Warrants & Moneyness & Days & BS-Market & GC-Market \\
\hline \multirow{2}{*}{ ERIBO } & in-the money & 16 & -0.5720 & -0.6062 \\
\hline & out-of-the-money & 58 & -0.6912 & -0.7967 \\
\hline ERICA & out-of-the-money & 72 & -0.7931 & -1.2600 \\
\hline ERICB & out-of-the-money & 67 & -0.8079 & -1.3958 \\
\hline ERICC & in-the money & 47 & -0.3161 & -0.2019 \\
\hline \multirow{2}{*}{ ERICD } & in-the money & 44 & -0.3007 & -0.2281 \\
\hline & at-the-money & 1 & -0.1768 & -0.4032 \\
\hline \multirow{2}{*}{ ERICE } & in-the money & 38 & -0.3259 & -0.2976 \\
\hline & out-of-the-money & 8 & -0.3340 & -0.6485 \\
\hline ERICF & in-the money & 50 & -0.3481 & -0.2311 \\
\hline ERICG & in-the money & 51 & -0.3051 & -0.2788 \\
\hline \multirow{3}{*}{ ERICH } & in-the money & 35 & -0.2045 & -0.4569 \\
\hline & at-the-money & 1 & -0.4590 & -0.9176 \\
\hline & out-of-the-money & 18 & -0.3393 & -0.9191 \\
\hline \multirow{2}{*}{ ERICI } & in-the money & 9 & 0.4206 & 0.2270 \\
\hline & out-of-the-money & 39 & -0.1508 & -0.7175 \\
\hline \multirow{2}{*}{ ERICJ } & in-the money & 8 & 0.3924 & 0.0434 \\
\hline & out-of-the-money & 33 & 0.1140 & -0.8501 \\
\hline \multirow{3}{*}{ ERICK } & in-the money & 1 & 0.2653 & -0.0917 \\
\hline & at-the-money & 1 & 0.3078 & -0.0769 \\
\hline & out-of-the-money & 51 & 0.0858 & -0.1592 \\
\hline \multirow{2}{*}{ ERICL } & in-the money & 15 & 0.0814 & -0.2883 \\
\hline & out-of-the-money & 24 & -0.3017 & -0.7652 \\
\hline \multirow{2}{*}{ ERICM } & in-the money & 6 & 0.1003 & 0.0182 \\
\hline & out-of-the-money & 37 & -0.2999 & -0.1852 \\
\hline ERICN & out-of-the-money & 38 & -0.2767 & -0.1805 \\
\hline ERIDA & out-of-the-money & 48 & -0.0612 & 0.0871 \\
\hline ERIDD & out-of-the-money & 40 & 0.0097 & 0.7632 \\
\hline ERIDE & in-the money & 45 & -0.0236 & -0.0668 \\
\hline \multirow{3}{*}{ ERIDF } & in-the money & 9 & 0.1018 & 0.0750 \\
\hline & at-the-money & 1 & 0.0010 & -0.0261 \\
\hline & out-of-the-money & 35 & -0.0194 & -0.1084 \\
\hline ERIDG & out-of-the-money & 39 & -0.0399 & -0.7447 \\
\hline ERIDH & in-the money & 53 & -0.0400 & -0.0323 \\
\hline \multirow{3}{*}{ ERIDI } & in-the money & 26 & -0.0437 & -0.1146 \\
\hline & at-the-money & 1 & -0.0023 & -0.1044 \\
\hline & out-of-the-money & 26 & -0.3087 & -0.4542 \\
\hline \multirow{3}{*}{ ERIDJ } & in-the money & 5 & -0.0580 & -0.1286 \\
\hline & at-the-money & 3 & -0.0216 & -0.1333 \\
\hline & out-of-the-money & 41 & -0.2119 & -0.4914 \\
\hline
\end{tabular}

* If stock price $>$ strike price warrant is said to be in the money (ITM), if the $S<K$ the warrant is out of the money (OTM) and if $S=K$ the warrant is at the money (ATM), (Lund University, 2016). 
Table: 8

The Pricing Differences of Models from the Market According to Moneyness of Put Warrants

\begin{tabular}{|c|c|c|c|c|}
\hline Codes of Warrants & Moneyness & Day & BS-Market & GC-Market \\
\hline ERITV & in-the money & 72 & -0.5158 & -0.5049 \\
\hline \multirow{2}{*}{ ERITY } & in-the money & 57 & -0.5577 & -0.5508 \\
\hline & out-of-the-money & 15 & -0.6986 & -0.6578 \\
\hline \multirow{2}{*}{ ERITZ } & in-the money & 21 & -0.6088 & -0.5927 \\
\hline & out-of-the-money & 48 & -0.6926 & -0.6322 \\
\hline ERIUP & out-of-the-money & 23 & -0.9726 & 28.5897 \\
\hline ERIUR & out-of-the-money & 16 & -0.98520 & 71.6176 \\
\hline ERIUS & out-of-the-money & 16 & -0.9956 & 100.4754 \\
\hline ERIUT & out-of-the-money & 53 & -0.4243 & 0.7498 \\
\hline ERIUU & out-of-the-money & 46 & -0.4045 & 2.1812 \\
\hline ERIUV & out-of-the-money & 43 & -0.5171 & 7.9013 \\
\hline \multirow{2}{*}{ ERIUY } & in-the money & 30 & 0.195 & -0.0841 \\
\hline & out-of-the-money & 24 & 0.1837 & -0.1655 \\
\hline \multirow{2}{*}{ ERIUZ } & in-the money & 6 & 0.1249 & 0.0147 \\
\hline & out-of-the-money & 33 & 0.644 & -0.5218 \\
\hline \multirow{2}{*}{ ERIVP } & in-the money & 17 & -0.0531 & -0.1714 \\
\hline & out-of-the-money & 55 & 0.1175 & -0.3779 \\
\hline ERIVR & in-the money & 44 & 0.185 & 0.1431 \\
\hline \multirow{2}{*}{ ERIVS } & in-the money & 45 & -0.0525 & 0.0069 \\
\hline & out-of-the-money & 6 & 0.1713 & 0.2785 \\
\hline \multirow{3}{*}{ ERIVT } & in-the money & 28 & -0.0559 & -0.0025 \\
\hline & at-the-money & 1 & -0.3174 & -0.2212 \\
\hline & out-of-the-money & 16 & 0.0164 & 0.1250 \\
\hline \multirow{2}{*}{ ERIVU } & in-the money & 36 & 0.0061 & 0.0707 \\
\hline & out-of-the-money & 34 & -0.1996 & -0.0827 \\
\hline \multirow{3}{*}{ ERIVZ } & in-the money & 47 & -0.058 & 0.0270 \\
\hline & at-the-money & 1 & -0.0819 & -0.0198 \\
\hline & out-of-the-money & 31 & -0.3412 & -0.2471 \\
\hline ERIYP & in-the money & 45 & -0.0304 & 0.0037 \\
\hline ERIYR & out-of-the-money & 36 & -0.2603 & -0.1214 \\
\hline ERIYS & out-of-the-money & 31 & -0.3606 & -0.1424 \\
\hline \multirow{3}{*}{ ERIYT } & in-the money & 26 & -0.1042 & -0.0944 \\
\hline & at-the-money & 1 & -0.0416 & -0.0491 \\
\hline & out-of-the-money & 26 & -0.1737 & -0.0796 \\
\hline ERIYU & out-of-the-money & 50 & -0.4859 & 1.1682 \\
\hline ERIYV & out-of-the-money & 35 & -0.6789 & 3.0142 \\
\hline
\end{tabular}

* If stock price $>$ strike price warrant is said to be in the money (ITM), if the $S<K$ the warrant is out of the money (OTM) and if $S=K$ the warrant is at the money (ATM), (Lund University, 2016).

Results of Table 7 and 8 are summarized on Table 9. Table 9 concludes that BlackScholes model is more appropriate to price call warrants and in-the-money days and out-ofthe-money days of put warrants. Gram-Charlier model can produce more accurate prices for put warrants at-the-money days than Black-Scholes model.

Table: 9

Average Price Deviations

\begin{tabular}{|l|c|c|c|c|}
\cline { 2 - 5 } \multicolumn{1}{c|}{} & \multicolumn{2}{c|}{ Call warrants } & \multicolumn{2}{c|}{ Put warrants } \\
\cline { 2 - 5 } \multicolumn{1}{c|}{} & BS & GC & BS & -0.13344 \\
\hline in-the money days & -0.06917 & -0.15643 & -0.117338 & 2.107927 \\
\hline out-of-the-money days & -0.26036 & -1.9252 & -0.35289 & -0.0967 \\
\hline at-the-money days & -0.05848 & -0.27692 & -0.146967 & \\
\hline
\end{tabular}

\section{Conclusion}

Investors face several risk factors in financial markets due globalization and indefinite future of financial systems. Investors need an effective risk management and various financial derivatives to overcome these risk factors. The covered warrants were 
issued in 2010 in Turkey to widen the variety of financial derivatives and strengthen investors against several financial risks. Determining accurate price of financial derivatives helps investors to control several financial risks.

This study is conducted to price covered warrants by Black-Scholes and GramCharlier pricing models and determine which model is more robust in reflecting the market price of warrants in Turkey. This study analyzes 23 call and 23 put covered warrants based on Eregli Demir Celik Fabrikaları T.A.S. stocks, issued and expired in 2015.

The results show that Black-Scholes model produces closer prices to the market for call option than Gram-Charlier model. However, Gram-Charlier model is more preferable to price put warrants in Turkey. Another result shows that prices of both Black-Scholes and Gram-Charlier model are not so close to observable market prices. Therefore, both of the models are not appropriate for pricing warrants traded in financial markets of Turkey. Another result shows that pricing performance of Black-Scholes for in-the-money, out-ofthe-money and at-the-money days of call warrants and in-the-money and out-of-the-money days of put warrants is better than Gram-Charlier model. On the other hand, Gram-Charlier model produces more accurate prices for at-the-money days of put warrants.

\section{References}

Akmehmet, Ö.M. (2012), "Varantların Teorik Fiyatının Piyasa Fiyatını Açıklama Gücü: Black ve Scholes Opsiyon Fiyatlama Modeli Çerçevesinde İMKB'de Bir Uygulama”, Yüksek Lisans Tezi, İstanbul Üniversitesi, İstanbul.

Alp, Ö.S. (2016), “The Performance of Skewness and Kurtosis Adjusted Option Pricing Model in Emerging Markets: A case of Turkish Derivatives Market", Journal of Finance \& Banking Studies, 5(3), 70-84.

Backus, D.K. \& S. Foresi \& L. Wu (2004), “Accounting for Biases in Black-Scholes”, Available at SSRN 585623.

Black, F. \& M. Scholes (1973), "The Pricing of Options and Corporate Liabilities", The Journal of Political Economy, 81(3), 637-654.

Boonchuaymetta, E. \& T. Kongtoranin (2007), "Warrant Pricing Model: An Empirical Study on the Valuation Models for Warrants Listed in Thailand", AU Journal of Management, 5(2), 56-66.

Chambers, N. (2012), Türev Piyasalar, İstanbul: Beta Basım Yayım Dağıtım A.Ş.

Chen, K.C. \& X.H. Liao (2010), "Expiration Effects of Covered Warrants in China", The Chinese Economy, 43(6), 54-75.

Chen, S.Y. (2003), "Valuation of Covered Warrant Subject to Default Risk", Review of Pacific Basin Financial Markets and Policies, 6(1), 21-44.

Chen, S.C. \& Y.C. Huang (2002), "Warrants Pricing: Stochastic Volatility vs. Black-Scholes", Pacific-Basin Finance Journal, 10(4), 393-409.

Deutsche Bank (2016), <https://www.xmarkets.db.com/TR/varant-nedir>, 01.12.2016.

Duan, J.C. \& Y. Yan (1999), "Semi-parametric Pricing of Derivative Warrants", Working Paper, Hong Kong University of Science and Technology.

Ekstrand, C. (2011), Financial Derivatives Modeling, Berlin: Springer. 
Fan, W. \& X. Yuan (2011), "Call Warrants in China's Securities Market: Pricing Biases and Investors' Confusion”, New Mathematics and Natural Computation, 7(02), 333-345.

Garanti Bankas1, (2016), <http://www.garantiyatirim.com.tr/Article.aspx?PageID=356>, 01.12.2016.

Higham, D.J. (2004), An Introduction to Financial Option Valuation-Mathematics, Stochastics and Computation, United States of America: Cambridge University Press.

İş Varant (2016), <http://www.isvarant.com/media/1827/varant-kitapcigi_110814.pdf>, 01.12.2016.

Jiratumpradub, N. \& W. Chavanasporn (2016), "Forecasting Option Price by GARCH Model", Information Technology and Electrical Engineering (ICITEE), 8th International Conference.

Karakuş, R. \& İ. Zor (2014), “İMKB’de İşlem Gören Aracı Kuruluş Varantları için Etkin Fiyatlama Modelinin Belirlenmesi”, Ege Academic Review, 14(1), 63-71.

Kleinert, H. \& J. Korbel (2016), “Option pricing Beyond Black-Scholes Based on Double-Fractional Diffusion”, Physica A: Statistical Mechanics and Its Applications, 449, 200-214.

Klinpratoom, A. (2010), "An Analysis of the Covered Warrants Market in UK”, Dissertation, University of Exeter, United Kingdom.

Liang, X. \& H. Zhang \& X. Li (2009), “A Simple Method of Forecasting Option Prices Based on Neural Networks", in: B.C. Chien \& T.P. Hong \& S.M. Chen \& M. Ali (eds), NextGeneration Applied Intelligence, IEA/AIE 2009, Lecture Notes in Computer Science, vol 5579, Springer, Berlin, Heidelberg.

Liang, X. \& H. Zhang \& J. Xiao \& Y. Chen (2009), "Improving Option Price Forecasts with Neural Networks And Support Vector Regressions", Neurocomputing, 72(13-15), 3055-3065.

Liu, M.H. \& N.K. Rangan (2012), “Trading Restrictions and Over-Valuation of Covered Warrants in China", 1-25.

London Stock Exchange (LSE) (2016), <http://www.lseg.com/areas-expertise/our-markets/borsaitaliana/fixed-income-markets/coverred-warrants>, 01.12.2016.

Lund University (2016), "Financial Mathematics Glossary", <http://www.maths.lth.se/matstat/research/mathematicalfinance/glossary/?word=Moneyn ess >, 01.12.2016.

Mansor, N.J. \& M.M. Jaffar (2014), "Black-Scholes Finite Difference Modeling in Forecasting of Call Warrant Prices in Bursa Malaysia", in: Proceedings of the $21^{\text {st }}$ National Symposium on Mathematical Sciences (SKSM21): Germination of Mathematical Sciences Education and Research towards Global Sustainability (Vol. 1605, No. 1, pp. 197-202), AIP Publishing.

Mutkin, L. (2015), Mispricing Derivatives A Danger for Real Assets, <https://www.ft.com/content/02d2e29c-9520-11e5-ac15-0f7f7945adba>, 16.04.2018.

Rouah, F.D. \& G. Vainberg (2007), Option Pricing Models and Volatility Using Excel-VBA, New Jersey: John Wiley \& Sons Ltd.

Siriopoulos, C. \& A. Fassas (2014), "An Analysis of the Covered Warrants Listed on the Athens Exchange", Journal of Risk \& Control, 1(1), 13-30.

Straja, S.R. (2003), "Derivative Valuation-Gram Charlier", Montgomery Investment Technology Inc., <http://www.fintools.com/wp-content/uploads/2012/02/DerivativeValuationGramCharlier.pdf>, 01.12.2016.

Temple, P. (2007), The Investor's Toolbox: How to Use Spread Betting, CFDs, Options, Warrants and Trackers to Boost Returns and Reduce Risk, Great Britain: Harriman House. 
Turkish Capital Markets Association (2016), <https://www.tspb.org.tr/uye-verileri/>, 01.12.2016.

World Federation of Exchanges (2016), <http://www.worldexchanges.org/home/index.php/statistics/monthly-reports>, 01.12.2016.

Wu, X.Y. \& C.Q. Ma \& S.Y. Wang (2012), "Warrant Pricing Under GARCH Diffusion Model”, Economic Modelling, 29(6), 2237-2244.

Yalincak, O.H. (2005), "Criticism of the Black-Scholes Model: But Why Is It Still Used? (The Answer Is Simpler than the Formula)", MPRA Paper No. 63208. 